\title{
Oral lesions presenting as an early sign of acute leukaemia
}

\author{
Zacharias Vourexakis
}

Department of Otolaryngology/ Head and Neck Surgery, University Hospital of Geneva, Geneva, Switzerland

\section{Correspondence to}

Dr Zacharias Vourexakis, zkvourexakis@yahoo.com

Accepted 13 January 2015
CrossMark

To cite: Vourexakis Z. BM Case Rep Published online: [please include Day Month Year] doi:10.1136/bcr-2014205100

\section{DESCRIPTION}

A middle-aged patient with no major comorbidity presented to the emergency department with severe odynophagia and painful oral lesions of 3 days' duration, and pronounced fatigue along with unusual recurrent bruising for almost a month.

Inspection of the oral cavity (figures 1 and 2) revealed ecchymoses on the hard palate and the floor of the mouth (blue arrows), ulcerations (white arrows) and pallor of the oral mucosa. The work-up included a complete blood count, karyotyping, microscopic examination and molecular biology studies of bone marrow biopsies. Severe pancytopenia (5 platelets/nL, 1.1 leucocytes $/ \mathrm{nL}$ and $22 \%$ haematocrit) along with a $\mathrm{t}(15 ; 17)(\mathrm{q} 24 ; \mathrm{q} 21)$ translocation were identified and findings were all compatible with the diagnosis of acute promyelocytic leukaemia (APML). Despite appropriate treatment, the patient died from intracranial haemorrhage occurring 3 weeks after initial admission to the hospital.

At initial presentation of leukaemia, oral manifestations may be present in 2/3 of all patients. ${ }^{1}$ None of these lesions is specific for the disease. It is the simultaneous presence of different types of oral lesions (haematomas, ulcers, gingival hypertrophy, opportunistic infections, etc) that should alert the physician. As APML represents one of the most curable but also most aggressive subtypes of acute leukaemia when left untreated, ${ }^{2}$ rapid and accurate diagnosis are crucial in its management. The treatment's efficacy increases drastically with the association of anthracycline-based chemotherapy regimens to a

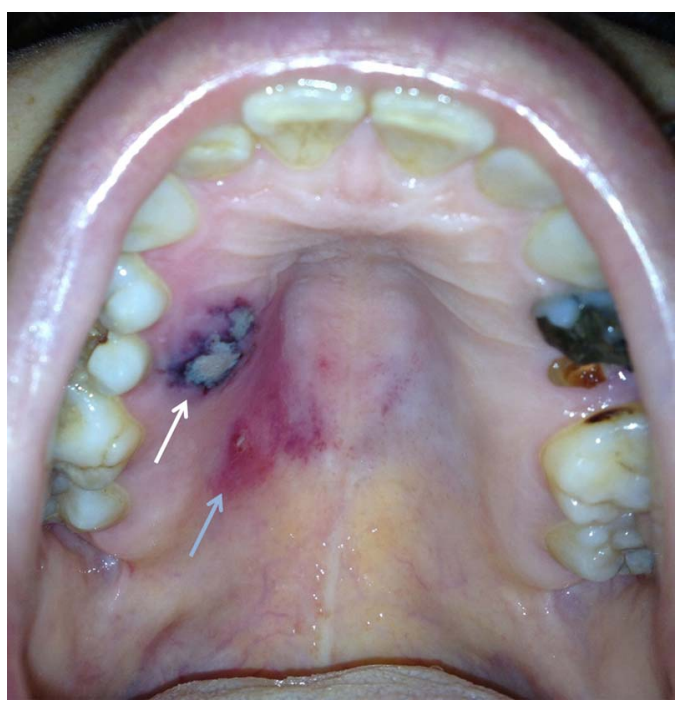

Figure 1 Ecchymosis (blue arrow) and mucosal erosion (white arrow) on the hard palate.

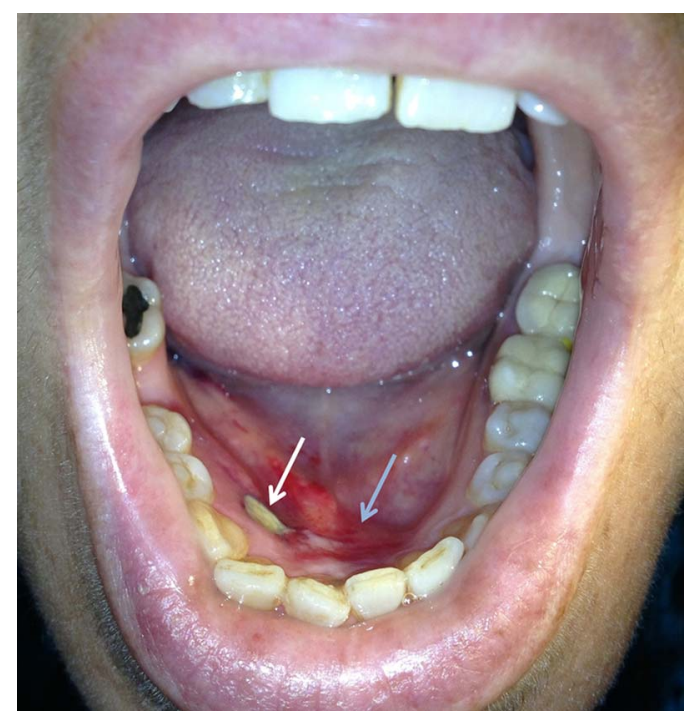

Figure 2 Ecchymosis (blue arrow) and ulceration (white arrow) on the floor of the mouth.

vitamin A derivative, the all-trans retinoic acid, with or without arsenic trioxide. Nowadays, the 5 -year disease-free survival of properly treated patients with APML may be well above $75 \% .^{3}$ Nevertheless, lifethreatening coagulopathy and lethal bleeding still represent a major risk for these patients.

\section{Learning points}

At initial presentation, two-thirds of patients with leukaemia have non-specific lesions of the oral mucosa.

- The simultaneous presence of different types of oral lesions (ulcers, haematomas, gingival hypertrophy, opportunistic infections, etc) should alert the physician for the possibility of an underlying disease and a haematological malignancy should be considered in the differential diagnosis.

- Acute promyelocytic leukaemia is a very aggressive form of leukaemia related to a characteristic acquired somatic mutation; it is highly curable when proper chemotherapy is associated to all-trans retinoic acid early in the course of the disease. 
Provenance and peer review Not commissioned; externally peer reviewed.

\section{REFERENCES}

1 Stafford R, Sonis S, Lockhart $P$, et al. Oral pathoses as diagnostic indicators in leukemia. Oral Surg Oral Med Oral Pathol 1980;50:134-9.
2 Dores GM, Devesa SS, Curtis RE, et al. Acute leukemia incidence and patient survival among children and adults in the United States, 2001-2007. Blood 2012;119:34-43.

3 Wang ZY, Chen Z. Acute promyelocytic leukemia: from highly fatal to highly curable. Blood 2008;111:2505-15.

Copyright 2015 BMJ Publishing Group. All rights reserved. For permission to reuse any of this content visit http://group.bmj.com/group/rights-licensing/permissions.

BMJ Case Report Fellows may re-use this article for personal use and teaching without any further permission.

Become a Fellow of BMJ Case Reports today and you can:

- Submit as many cases as you like

- Enjoy fast sympathetic peer review and rapid publication of accepted articles

- Access all the published articles

- Re-use any of the published material for personal use and teaching without further permission

For information on Institutional Fellowships contact consortiasales@bmjgroup.com

Visit casereports.bmj.com for more articles like this and to become a Fellow 